\title{
Synchronous Bilateral Testicular Germ Cell Tumour: Case Report and Review of the Literature
}

\section{Synchronní bilaterální testikulární tumor ze zárodečných buněk: kazuistika a přehled literatury}

Detti B. ${ }^{1}$, Scoccianti S. ${ }^{\text {, Cassani S. }}{ }^{1}$, Franzese C. ${ }^{1}$, Di Cataldo V. ${ }^{1}$, Villari D. ${ }^{2}$, Cai T. ${ }^{3}$, Desideri I. ${ }^{1}$, Livi L. ${ }^{1}$, Lapini A. ${ }^{4}$, Nicita G. ${ }^{2}$, Carini M. ${ }^{4}$, Biti G. ${ }^{1}$

\author{
${ }^{1}$ Radioterapia, Azienda Ospedaliero-Universitaria Careggi, Florence, Italy \\ ${ }^{2}$ Clinica Urologica II, University of Florence, Florence, Italy \\ ${ }^{3}$ Department of Urology, Santa Chiara Hospital, Trento, Italy \\ ${ }^{4}$ Clinica Urologica I, University of Florence, Florence, Italy
}

\begin{abstract}
Summary
We report a case of a 30 years old male affected by synchronous bilateral germ cell tumor with a history of unilateral cryptorchidism; the patient underwent surgical treatment followed by adjuvant radiotherapy on para-aortic and iliac lymphnodes. Patients with synchronous tumors usually present with a higher stage disease in contrast to those with unilateral testicular carcinoma, yet the prognosis remains equally favorable.
\end{abstract}

Key words

bilateral seminoma - cryptorchidism - radiotherapy - testicular cancer - germ cell tumor

\section{Souhrn}

Tento článek popisuje př́pad 30letého muže s anamnézou jednostranného kryptorchidizmu, postiženého synchronním tumorem varlete. Pacient podstoupil chirurgickou resekci a následně adjuvantní radioterapii na oblast paraaortálních a ilických lymfatických uzlin. Pacienti se synchronní duplicitou jsou zpravida diagnostikováni ve vyšším stadiu onemocnění, nicméně prognóza u nich zůstává podobně př́znívá jako u pacientů s jednostranným postižením.

\section{Klíčová slova}

bilaterální seminom - kryptorchizmus - radioterapie - testikulární rakovina nádor ze zárodečných buněk
The authors declare they have no potential conflicts of interest concerning drugs, products, or services used in the study.

Autor̆i deklarují, že $v$ souvislosti s predmětem studie nemaji žádné komerční zájmy.

The Editorial Board declares that the manuscript met the ICMJE "uniform requirements" for biomedical papers.

Redakční rada potvrzuje, že rukopis práce splnil ICMJE kritéria pro publikace zasílané do biomedicínských časopisů.

$\Xi^{\circ}$

Beatrice Detti, MD

Radiotherapy Unit

Azienda Ospedaliero-Universitaria

Careggi

Viale Morgagni 85

50144 Florence

Italy

e-mail: beatrice.detti@aouc.unifi.it

Submitted/Obdrženo: 8. 1. 2013

Accepted/Príijato: 3. 3. 2013 


\section{Introduction}

Testicular cancer is the most common solid malignancy in men between the ages of 15 to 35 years and the incidence has increased significantly over the last two decades [1]. Patients with testicular carcinoma in one testis are 500-1,000 times more likely to develop testicular carcinoma in the contralateral testis. The incidence of bilateral germ cell tumors (BGCT) varies between 0.5 and $7 \%$, they occur metachronously in $80-85 \%$ of cases and synchronously in $15-20 \%$ of cases [2,3]. Cryptorchidism, atrophy, trauma and hormonal or genetic factors are known risk factors for the development of a testicular germ cell tumor [4]. We report a case of a young man affected by synchronous bilateral germ cell tumors (SBGCT) with a history of unilateral cryptorchidism; the patient underwent surgical treatment followed by adjuvant radiotherapy on para-aortic and iliac lymph-nodes, since he suffered a stage II seminoma. Patients with synchronous tumors usually present at a higher stage disease, compared with those with unilateral testicular carcinoma; however the outcome remains excellent.

The treatment of patients with bilateral germ cell tumors is based on the pathology and clinical stage and should not be different from the standard management of unilateral testicular carcinoma.

\section{Case Report}

A 30-year old male firstly presented with fertility disorder in January 2011. Scrotal color Doppler sonography revealedan inhomogeneous nodule with microcalcifications in the superior pole of the right testis and another small nodule in the superior pole of the left testis.

Past medical history is noteworthy for right criptorchiectomy in two years of age. The patient underwent right orchifunilectomy with a placement of a testicular prosthesis and exstirpation of the left testis nodule. The histo-pathological examination revealed bilateral seminoma; the right tumor mass measuring $2.5 \mathrm{~cm}$ in diameter, with peritumoral vascular and lymphatic vessel invasion. The left nodule was $0.3 \mathrm{~cm}$ in diameter. The staging CT scan showed lymphadenopathy within the para-aortic and the right com-

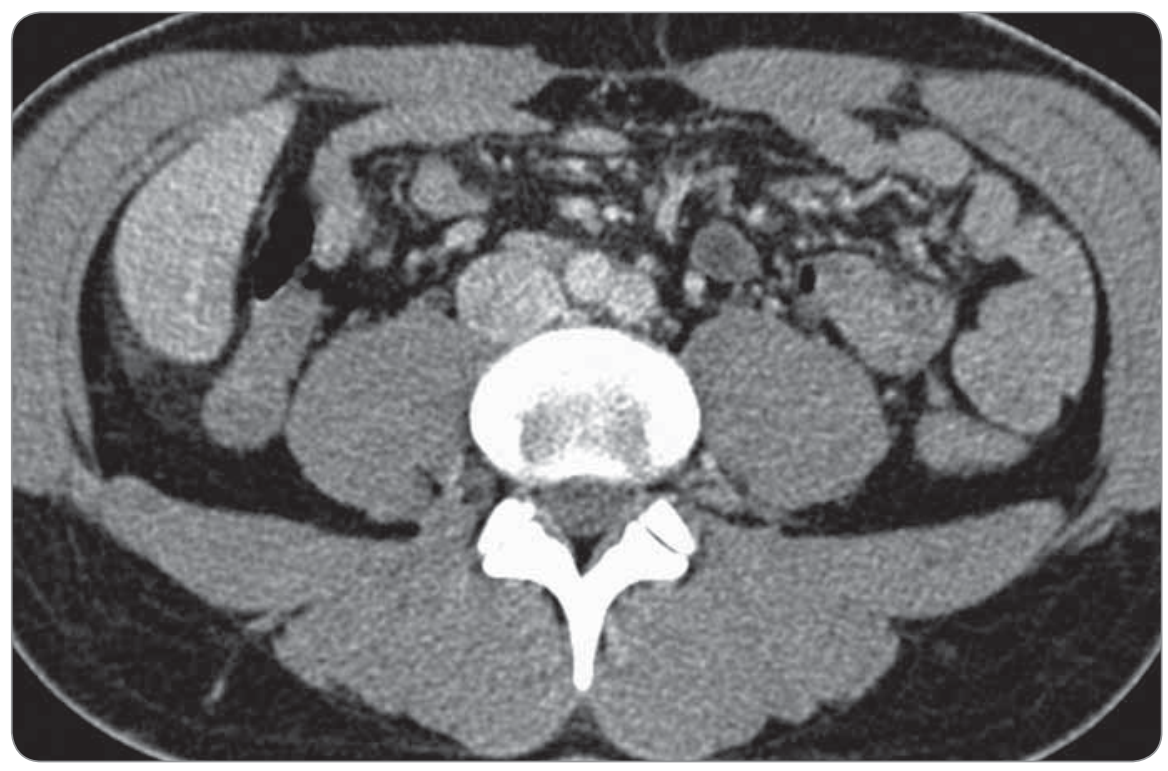

Fig. 1. Axial CT of pathologic para-aortic lymph nodes.

mon iliac nodal chains, with the largest node up to $34 \mathrm{~mm}$ (Fig. 1-3). Tumor markers (a-fetoprotein, $\beta$-human chorionic gonadotropin and LDH) drawn in preoperative and in postoperative phases both resulted negative.

The case was discussed at the MDT meeting and it was proposed to perform radiotherapy on paraortic and ipsilateral iliac lymph nodes - the so called dog-leg field.

For further management of the left testis after the sparing surgery there where two therapeutic options discussed with the patient: low dose radiotherapy to the remaining testicle or carefull surveillance with regular scrotal sonography. The patient preferred the close follow-up to testicular irradiation.

Hence radiation therapy on dog-leg volume was performed in March 2011 with a total dose of $36 \mathrm{~Gy}$ in 18 fractions delivered from two opposite fields. The treatment was well tolerated, with only grade one nausea during the first days of therapy.

Two months following the radiotherapy a new $\mathrm{CT}$ showed complete remission of the metastatic lymphadenopathy. At the last follow-up, 24 months after the initial diagnosis, there was no evidence of relapse.

\section{Discussion}

Cryptorchidism is a known risk factor for the development of a testicular germ cell

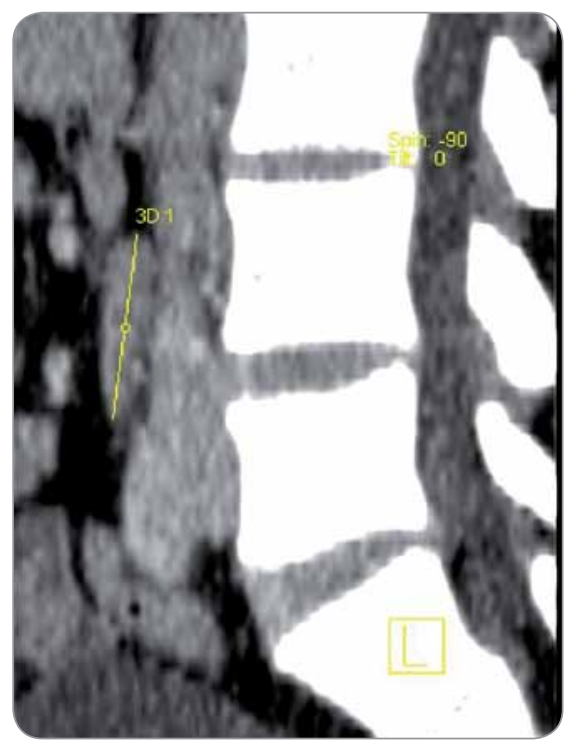

Fig. 2. Sagittal CT of pathologic para-aortic lymph nodes.

tumor. Maldescent testis is thought to be associated with a 2-4 fold increased risk of testicular cancer, although some studies have even reported a 5-10 fold increased relative risk [5]. In another study a history of cryptorchidism was recorded in $9-10 \%$ of patients with bilateral germ cell tumors in contrast to only $2 \%$ incidence in a group of patients with unilateral germ cell tumors. This work refers a patient with a history of unilateral cryptorchidism. Notable is also a recent work of García et al presenting a patient affected by Down 
syndrome with a history of bilateral untreated cryptorchidism, reffered for bilateral orchidectomy [6].

One of the earliest mentions of bilateral testicular germ cell tumors was can be found in the work of Gilbert and Hamilton in 1941. The authors reported 1,466 patients with primary testicular tumors discovering that $1.6 \%$ of patients had bilateral testicular involvement [7]. In 1978, Aristizabal et al published a review covering the literature on testicular neoplasms over a period of two decades, with an overall incidence of bilateral tumors being $1.56 \%$ among 4,864 patients [8].

One of the largest series of bilateral testicular cancer was presented by Holzbeierlein et al, there was registered a total of 58 patients treated at Memorial Sloan Kettering Cancer Center between the years 1950 and 2001. Among these patients 48 had metachronous and 10 had synchronous bilateral germ cell tumors. Of these, six (60\%) patients presented with stage I disease, two (20\%) presented with stage II disease and only one (10\%) presented with stage III disease. During a median follow-up of 30 months, there were no relapses noted among the patients. The authors reported outcomes similar to those in patients with unilateral testicular tumors when matched by stage. In the series from MSKCC no patient underwent a testis sparing surgery [9].

At Indiana University, there were 21 patients (1\%) suffering a bilateral invasion among a total of 2,088 patients diagnosed with a testicular carcinoma The tumors occurred subsequently in 16 cases and the rest of the patients presented with synchronous testicular tumors. During a mean follow-up of 50 months, 18 patients remained without any evidence of the disease, two were alive with a persisting tumor and one patient died of the disease [2].

In another study from MD Anderson Cancer Center, BGCT comprised 1\% of the total incidence of testicular tumors. Findings were based on the evaluation 2,431 patients with testicular germ cell tumors over the survey period from 1978 to 1999 . Twenty of 24 patients with bilateral germ cell tumors developed the

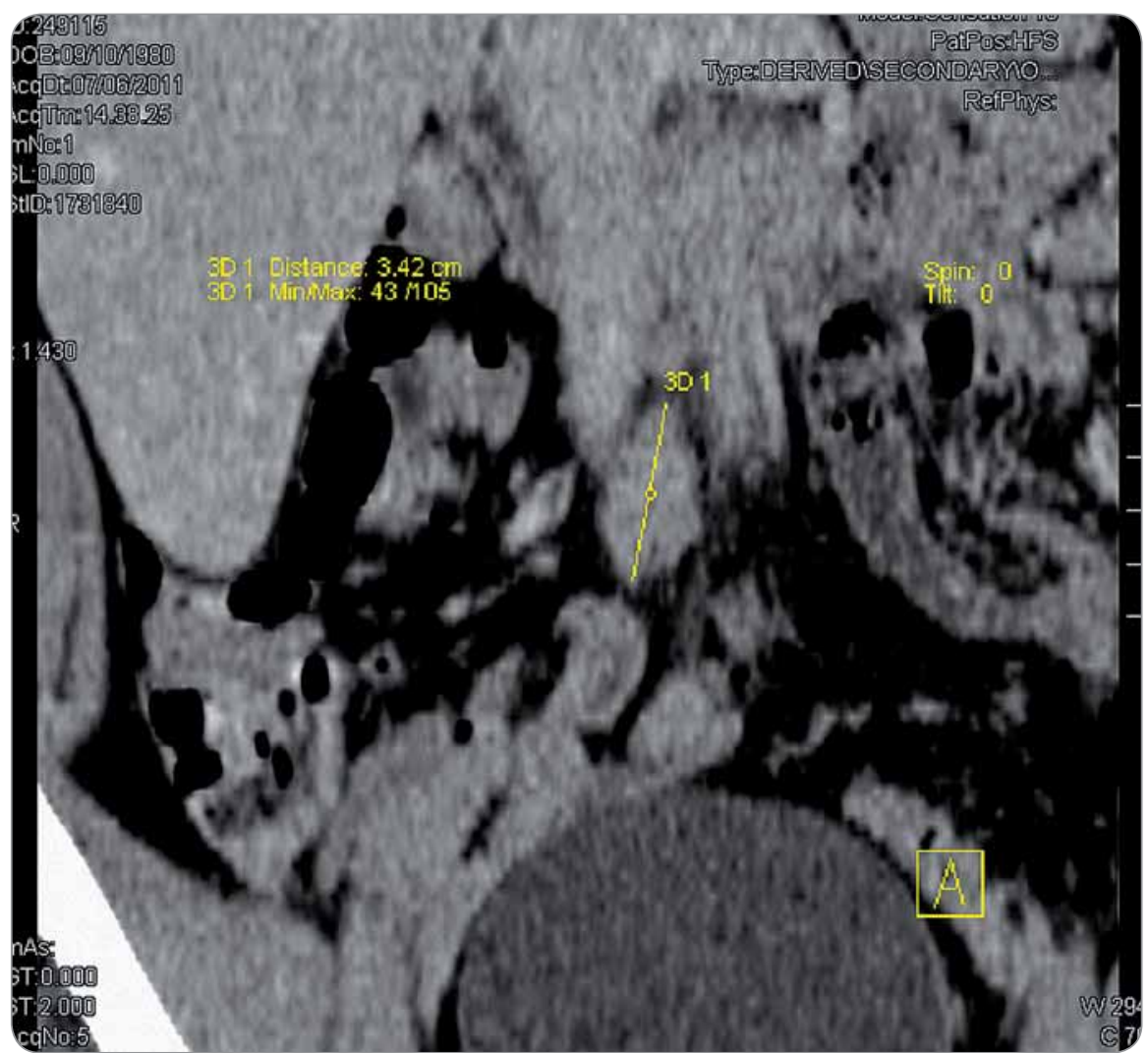

Fig. 3. Coronal CT of pathologic para-aortic lymph nodes.

tumor consecutively and four patients had synchronous tumors. The therapeutic outcomes were excellent, since only one man died of metastatic disease [4].

In 2004 Theodore et al described the incidence, clinical and histological characteristics, treatment and long-term follow-up of 45 patients with bilateral germ cell tumours. 31 patients in the review group had metachronous BGCT while 14 had synchronous tumours. The cure fraction of BGCT was excellent, only one patient with poor prognosis disease, as defined by the IGCCCG staging system, died of refractory metastatic disease. A strong correlation between bilateral testis cancer, sterility and suspected genetic risk factors was found [3]. A few years later, several studies have shown that testicular germ cell tumours are associated with an overpresentation of the short arm of chromosome 12. This genetic alteration is found in almost all testicular germ cell tumours $[10,11]$.

More recently, Morales-Barrera et al examined retrospectively 151 patients affected by testicular germ cell tumors. Eight (5.3\%) patients developed bilateral tumours, metachronous tumors made up seven $(4.6 \%)$ of the cases in the review group and there was one $(0.7 \%)$ synchronous tumour reported. Two patients underwent testis-sparing surgery for the second tumor. The authors concluded that the survival rate in the group of patients with bilateral testicular germ cell tumours is similar to that of patients with unilateral testicular germ cell tumours [12].

As for the treatment modalities, bilateral orchiectomy remains the treatment of choice for bilateral testicular cancer. Unfortunately, this procedure generates significant endocrine and psychological disorders, such as infertility, necessity of androgen replacement therapy and other adverse effects of castration. This approach is elected on the basis of the size of the primary lesion and the expected multifocality of the tumor.

Testis sparing surgery, as an alternative method with a capacity to preserve fertility and to avoid lifelong need of androgen replacement therapy, was firstly presented by Richie in 1984 [13]; he performed a hemi-orchidectomy in a patient with bilateral seminoma and the 
patient, although infertile, remained free of disease without any need of androgen supplementation. Testis sparing surgery can be performed only in select cases (tumors smaller than $25 \mathrm{~mm}$ confined to the testis and with normal preoperative testosterone).

The German Testicular Cancer Intergroup recommend that organ sparing surgery should always be considered in the management of bilateral as well as solitary germ cell tumour in order to maintain the quality of life and to prevent endocrinological disorder arising from subnormal testosterone serum levels, regardless of the androgen substitution [14].

Recently, Klatte et al reported 25 years' experience from the Department of Urology of the University of Magdeburg, Germany based on an evaluation of 612 patients treated for testicular germ cell tumors between 1982 and 2007. Among 17 patients with bilateral invasion eleven (65\%) were diagnosed with metachronous and six (35\%) with synchronous disease. The median age of these six patients was 31 years. Four of them presented with bilateral seminoma, whereas the other two developed a seminoma followed by contralateral non-seminoma tumor. The authors suggested that organ-sparing surgery may be performed in selected cases, in both bilateral or unilateral GCT [15].

Our patient was treated with testis sparing surgery for the contralateral testicular tumor, proceeded by a close follow-up including a scrotal sonography, in order to preserve fertility and hormonal state.

Tekin et al [16] described the management of 11 patients with bilateral testicular germ cell tumors, treated by bilateral orchiectomy followed by androgen substitution, namely by administering testosterone depots. After a median follow-up of 53 months there was no record of recurrent disease among the patients. None of the patients lost libido, potency neither experienced other side-effects of testosterone replacement therapy.

As an alternative to bilateral surgery in synchronous bilateral seminoma some authors advocated only unilateral orchiectomy for the major tumor, followed by three courses of BEP chemothe- rapy [17]. In other works systemic chemotherapy appears to have a protective effect against the development of a second testicular tumor. Van Basten et al noted that the risk of developing a contralateral tumor was reduced from 5.0\% to $1.8 \%$ in the group of men treated by cisplatin-based chemotherapy [18]. This result indicates certain significance of chemotherapy in elimination of TIN or early testicular cancer. Bokemeyer et al also confirmed the notion that the use of chemotherapy has eradicated the cancer in contralateral testis [19]. Similarly, Oliver et al suggest that one cycle of adjuvant carboplatin is likely to achieve relapse-free survival rates comparable to prophylactic radiotherapy in patients with clinical stage I seminoma [20]. Contrasting results were presented in a study of Pamenter et al who reported 19 (3.3\%) men developing second testicular malignancy after the initial treatment for testicular cancer. These findings were based on evaluation of 570 men with testicular cancer treated in Western Scotland in the period 1989-1998. In their experience, the chemotherapy did not prove to eliminate the risk of developing a contralateral tumour [21].

The EAU (European Associaton of Urology) Guidelines reported that in synchronous bilateral testicular tumours the organ-sparing surgery can be beneficial, even though the rate of associated TIN is high. The standard treatment for low-volume metastatic (stage IIA/B) seminoma has been radiotherapy at a total dose of 30-36 Gy, delivered to the hockey-stick field (from the para-aortic region to ipsilateral iliac nodes). Chemotherapy with three cycles of BEP or four cycles of EP is an alternative to nodal radiotherapy.

Risk-adapted chemotherapy with three cycles of BEP or four cycles of EP remains an alternative to radiotherapy in stage IIB seminoma, with comparable therapeutic outcome, however, it is associated with higher acute and long-term toxicity [22]. The recommended radiotherapy should achieve a total dose of $30 \mathrm{~Gy}$ for stage IIA and $36 \mathrm{~Gy}$ for stage IIB respectively; whereas the standard radiation field should encompass both the para-aortic and the ipsilateral iliac re- gion [23]. The relapse rates are moderate ( $5 \%$ in stage IIA, $11 \%$ in stage IIB) and the overall survival of patients with seminoma stage II is almost $100 \%[24,25]$.

Over the past 50 years, RT to the lymph nodes has been the treatment of choice for seminoma. Recently, the concern about its side effects, in particular the cardiovascular toxicity and secondary malignancies, has led investigators to attempt to minimize the radiation exposure or to find an alternative therapeutic modality. In fact, several investigations have demonstrated a significantly increased risk of secondary cancers, especially in the upper gastrointestinal tract and the bladder. The largest study addressing the secondary neoplasms in long-term survivors of testicular cancer was conducted by Travis et al [26]; they reported 1,406 secondary cancers among 29,000 patients and a 1.43 observed-to-expected ratio of developing a secondary tumor. Although the changes in field size and RT dose over the last 20 years have brought about a better tolerance with limited side effects, the concerns related to the risk of long-term toxicity should not be ignored or neglected.

\section{Conclusions}

Synchronous bilateral germ cell tumors remain rare among testicular malignancies and each patient requires a tailored treatment, because only few data on the optimal management exist nowadays. The correlation with prior cryptorchidism is actually controversial, as the results vary widely among the studies. Although patients with synchronous bilateral germ cell tumors present with a higher stage disease, they usually have an excellent prognosis. In order to avoid hormonal deficit and, consequently, further decline in quality of life, testis sparing surgery instead of bilateral orchiectomy should be performed in accurately selected cases. Patients with unilateral germ cell tumor require careful long-term monitoring of the remaining testicle due to a significantly increased risk of contralateral disease.

\section{References}

1. Patel SR, Richardson RL, Kyols L. Synchronous and methacronous bilateral testicular tumors: Mayo Clinic experience. Cancer 1990; 65(1): 1-4. 
2. Coogan CL, Foster RS, Simmons GR et al. Bilateral testicular tumors: management and outcome in 21 patients. Cancer 1998; 83(3): 547-552.

3. Theodore C, Terrier-Lacombe MJ, Laplanche A et al. Bilateral germ-cell tumours: 22-year experience at the Institut Gustave Roussy. Br J Cancer 2004; 90(1): 55-59.

4. Che M, Tamboli P, Ro JY et al. Bilateral testicular germ cell tumors: twenty-year experience at M.D. Anderson Cancer Center. Cancer 2002; 95(6): 1228-1233.

5. Garner MJ, Turner MC, Ghadirian P et al. Epidemiology of testicular cencer: an overview. Int J Cancer 2005; 116(3): 331-339.

6. García MA, Gutiérrez GJ, Ortiz LGE et al. Synchronous bilateral testicular seminoma in an adult patient with bilateral cryptorchidism: a case report and literature review. Actas Urol Esp 2010; 34(2): 210-211.

7. Gilbert JB, Hamilton JB. Studies in malignant tumors of the testis. IV. bilateral testicular cancer. Incidence nature, and bearing upon management of the patient with a single testicular cancer. Cancer Res 1942; 2: 125-129.

8. Aristizabal S, Davis JR, Miller RC et al. Bilateral primary germ cell testicular tumors: report of four cases and review of the literature. Cancer 1978; 42(2): 591-597.

9. Holzbeierlein JM, Sogani PC, Sheinfeld J. Histology and clinical outcomes in patients with bilateral testicular germ cell tumors: the Memorial Sloan Kettering Cancer Center experience 1950 to 2001. J Urol 2003; 169(6): 2122-2125.
10. Kanetsky PA, Mitra N, Vardhanabhuti S et al. Common variation in KITLG and at 5 q31.3 predisposes to testicular germ cell cancer. Nat Genet 2009; 41(7): 811-815.

11. Korkola JE, Houldsworth J, Feldman DR et al. Identification and validation of a gene expression signature that predicts outcome in adult men with germ cell tumors. J Clin Oncol 2009; 27(31): 5240-5247.

12. Morales-Barrera R, Valverde C, Rodón J et al. Bilatera testicular germ cell tumours: a single hospital experience. Clin Transl Oncol 2010; 12(4): 299-302.

13. Richie JP. Simultaneous bilateral tumors with unorthodox management. World J Urol 1984; $2: 74$

14. Heidenreich A, Weissbach L, HöltI W et al. Organ sparing surgery for malignant germ cell tumor of the testis. J Urol 2001; 166(6): 2161-2165

15. Klatte T, De Martino M, Arensmeier K et al. Management and outcome of bilateral testicular germ cell tumors: a 25-year single center experience. Int J Urol 2008; 15(9): 821-826.

16. Tekin A, Aygun YC, Aki FT et al. Bilateral germ cell cancer of the testis: a report of 11 patients with a long-term follow-up. BJU Int 2000; 85(7): 864-868.

17. Tomita E, Kondo T, Nakazawa $\mathrm{H}$ et al. Successful testis preservation for bilateral testicular tumors with a new chemotherapy-based protocol: initial results of three cases. Int J Urol 2007; 14(9): 879-882.

18. van Basten JP, Hoekstra HJ, van Driel MF et al. Cisplatin-based chemotherapy changes the incidence of bilateral testicular cancer. Ann Surg Oncol 1997: 4(4): 342-348.
19. Bokemeyer C, Schmoll HJ, Schöffski P et al. Bilateral testicular tumours: prevalence and clinical implications. Eur J Cancer 1993; 29A(6): 874-876.

20. Oliver RT, Mason MD, Mead GM et al. Radiotherapy versus single-dose carboplatin in adjuvant treatment of stage I seminoma: a randomized trial. Lancet 2005; 366(9482): 293-300.

21. Pamenter B, De Bono JS, Brown IL et al. Bilateral testicular cancer: a preventable problem? Experience from a large cancer centre. BJU Int 2003; 92(1): 43-46.

22. Garcia-del-Muro X, Maroto P, Gumà J et al. Chemotherapy as an alternative to radiotherapy in the treatment of stage IIA and IIB testicular seminoma: a Spanish Germ Cell Cancer Group Study. J Clin Oncol 2008; 26(33): 5416-5421. 23. Winter C, Albers P. Testicular germ cell tumors: pathogenesis, diagnosis and treatment. Nat Rev Endocrinol 2011; 7(1): 43-53.

24. Classen J, Schmidberger H, Meisner C et al. Radiotherapy for stages $\mathrm{IA} A / \mathrm{B}$ testicular seminoma: final report of a prospective multicenter clinical trial. J Clin Oncol 2003; 21(6): 1101-1106.

25. Schmidberger H, Bamberg M, Meisner C et al. Radiotherapy in stage IIA and IIB tesicular seminoma with reduced portals: a prospective multicenter study. Int J Radiat Oncol Biol Phys 1997; 39(2): 321-326

26. Travis LB, Fossa SD, Schonfeld SJ et al. Second cancers among 40,576 testicular cancer patients: focus on long-term survivors. J Natl Cancer Inst 2005; 97(18): 1354-1365. 